\title{
Habituation of exploratory activity in aged rats: effects of pyritinol
}

\author{
Roberto DeLucia ${ }^{1 *}$, Inês Aparecida Buscariolo², Moacyr Luiz Aizenstein¹ \\ ${ }^{1}$ Departamento de Farmacologia, Instituto de Ciências Biomédicas, Universidade de São Paulo, ${ }^{2}$ Departamento de \\ Estomatologia, Faculdade de Odontologia, Universidade de São Paulo.
}

*Correspondence:

R. DeLucia

Departamento de Farmacologia

Instituto de Ciências Biomédicas-USP

Av. Lineu Prestes, 1524

05508-900 São Paulo-SP- Brasil

Email: rdelucia@icb.usp.br
Acetylcholine (Ach) is a neurotransmitter considered to play a critical role in processes underlying behavior, learning, and memory. Pyritinol (pyrithioxine, Encephabol $\left.{ }^{\hat{a}}, P R T\right)$ is a nootropic drug that increases cholinergic transmission in the central nervous system. Behavioral habituation following multiple exposures to an open field is an experimental paradigm frequently used to assess the cognitive actions of drugs. In this paradigm the decrease of exploratory activity as a function of repeated exposure to the same environment is taken as an index memory. In the present study, effects PRT administrated to aged rats in powder form added to the diet (200 mg / $\mathrm{kg} /$ day, p.o., for 14 days) were evaluated in the habituation to an open field. A total of 18 aged rats were randomly assigned to one of two groups control (vehicle-treated rats, $n=8$ ) and experimental group (PRT-treated rats, $n=10)$ and were used in the following procedure. In the exploratory task, the post-training treatment with PRT significantly decreased the number of total area crossings and rears when compared to the control group, indicating habituation. PRT treatment enhanced retention in the total number of area crossings and rears when compared with control animals. Taken together, the data of present study suggest that muscarinic cholinergic systems could be involved in the effect of PRT in habituation of exploratory activity to an open field in aged rats.

\section{Uniterms}

- Habituation

- Open field,

- Pyritinol

- Memory

- Cholinergic system

\section{INTRODUCTION}

The neurotransmitter acetylcholine (ACh) is considered to play a critical role in processes underlying many aspects of behavior, learning, and memory (e.g. Bartus et al., 1970; Gold, 2003; Fibiger, 1991).

Pyritinol (Pyrithioxine, Encephabol ${ }^{\circledR}$, PRT) is a nootropic drug with few side effects (Cooper, Magnus,
1981). Basically this drug is prescribed for treatment of organic psychosyndromes including senile dementia such as Alzheimer'disease (Zyhov, Begasheva, 2003; Knezevic et al., 1989; Cooper, Magnus, 1981). PRT is also prescribed for antagonized the depressant effects of anesthetics drugs (Martin, 1983). Moreover, behavioral and electrophysiological data have shown that PRT produces an alerting response in both animals and men (Dolce, 
1970). However, little has been reported about the effects of PRT in the memory.

It has been suggested that the use of cholinomimetic drugs and the consequent enhancement of cholinergic activity, improves memory in elderly individuals (Ibach, Haen, 2004). In line with this view, several cholinergic agents, such as the cholinesterase inhibitor physostigmine and the muscarinic agonist bethanechol have been used in animal models in order to potentiate central cholinergic transmission (Bartus et al., 1987; Whitehouse, 1986).

In a study concerned with changes in neurotransmitter systems as function of aging, Martin, Vyas (1987) investigated the age-related effects of PRT in different neurotransmitter's systems. They showed that PRT led to an increase in the levels of endogenous ACh in the cortex and the striatum of aged rats, when compared with young animals. Moreover, it has been also shown that PRT increases ACh levels in old rats, an effect probably related to changes in phospholipids of the membranes (Martin, Widdowson, 1990).

The effects of nootropic drugs in the memory can be demonstrated by a series of experimental paradigms. However, these effects are dependent on age, animal species, dose and learning efficiency (DeLucia et al., 1991; Judd et al., 1987).

Behavioral habituation following repeated exposures to an open field is an experimental paradigm frequently used to assess the cognitive actions of drugs.

Habituation is defined as the decrement for a response to an unreinforced stimulus, as result of repeated presentations of that stimulus (e.g. File, 1976). The neurochemical substrate for the habituation process is not fully understood, but the central muscarinic cholinergic system seems to be essential for the habituation of exploratory behavior as postulated several years ago by Carlton (1968). Additionally, a neurochemical study in vivo showed that increased extracellular levels of hippocampal ACh correlate with the behavioral habituation in an exploratory task performed in an open field (Thiel et al., 1998). Moreover, Koph, Baratti, (1996) showed that glucose modulates memory storage during habituation. According to them, this effect seems to be mediated via an enhancement of brain ACh synthesis and its releasing.

Considering the effects of PRT on chlolinergic transmission and the role of this neurotransmitter in cognitive processes the aim of the present study was to evaluate the effects of PRT in the cognitive function. Our approach was to evaluate the effect of PRT in the habituation of the exploratory behavior of rats re-exposed to an open field.

\section{MATERIAL AND METHODS}

\section{Animals}

The animals used in the experiment were male Wistar rats provided by the breeding colony of Escola Paulista de Medicina (Universidade Federal de S. Paulo). Groups of rats $(n=6)$ were housed in plastic cages 32 (width) $\times 40$ (length) $\times 16$ (height) $\mathrm{cm}$ in a room maintained at $22 \pm 1{ }^{\circ} \mathrm{C}$ and illuminated by white light at 100 lux. The animals were maintained under a 12:12-h light/dark (LD) regimen, lights on from 07:00 to 19:00 $\mathrm{h}$ for 9 weeks before the experiment. Food and water were freely available. When the animals were 20 months old, weighing $480 \pm 30$ $\mathrm{g}$ they were used in the experiment. Seven days before the experiment the animals were individually housed in wire mesh cages 15 (width) x 30 (length) x 19 (height) cm with continuous access to food and water except during the observation period.

\section{Treatment}

A total of 18 aged rats were randomly assigned to one of two control groups $(\mathrm{n}=8)$ and experimental group $(\mathrm{n}=$ 10). The experimental animals received PRT in powder form $(200 \mathrm{mg} / \mathrm{kg} /$ day $)$ which was added to the normal diet (standard Purina ${ }^{\circledR}$ ). The dose of PRT and time of treatment were selected according to the report of Martin and Vyas, (1987). Control group received a similar amount of normal diet. The drug and food consumed was measured daily and recorded over an entire $24 \mathrm{~h}$ period. The rats took all the drug without any difficulties.

\section{Experimental procedure}

The open field consisted of a wooden arena, with 200 $\mathrm{cm}$ in diameter bounded by $30 \mathrm{~cm}$ high walls. The interior was painted white and the floor of it was divided into 30 areas by black lines. The illumination was maintained by white light (fluorescent bulb, 100 lux at open field level). After 14 days of treatment, rats of the control and experimental groups were subjected to 2 sessions of the same task: one for training (first session) and one for testing (second session). During the training and testing sessions, the animals were placed individually in the open field, and allowed to explore the arena for $5 \mathrm{~min}$. Total area entries (number of times the animals crossed one area with the four paws) and rears (both front feet off on the arena floor) and non exploratory behavior (duration of stationary behavior) were counted in both sessions. The differences in the number of total area entries and rears between the 
test and training trials were used as the measure of retention. In addition, the frequency of entries made into the outer (i.e. those immediately adjacent to the walls) and inner (i.e. those at least one area removed from the walls) were counted. Each animal was tested one day after training. The observer was not aware of the treatments and was the same for all observations that were performed between 09.00 and 11.00 a.m.

\section{Statistical analyses}

Data were analyzed by Kruskall-Wallis'test. Significant difference was assigned only if $\mathrm{P}$ value was lower than 0.05 in statistical test.

\section{RESULTS}

\section{Evaluation of the effects of PRT in habituation to an open field}

As illustrated in figure 1 (A and B), treatment with PRT (200 mg/kg per day, p.o. for 14 days) significantly decreased the number of total area entries and rears as compared to the control group during the post-training ( $\mathrm{p}$ $<0.05$; Kruskal-Wallis'test). However, no differences were observed between groups during the training session 1 .

Figure $1 \mathrm{C}$ shows the ratio of inner to total area entries for the animals from control group and treated with PRT. There were no group differences on these measures in both sessions.

Figure 1D displays duration of non-exploratory behavior in the two groups over the training and test session. The duration of non-exploratory behavior in PRT treated animals was significantly greater than that for control animals in both sessions.

\section{DISCUSSION}

Several pharmacological approaches have been used to study habituation (Lamprea et al., 2003; Schildein et al., 2002; Rowe et al., 1998; Moliengo et al., 1995; Willians et al., 1974). One rationale behind these approaches is the elucidation of the neural mechanism related to the effects of drugs in habituation.

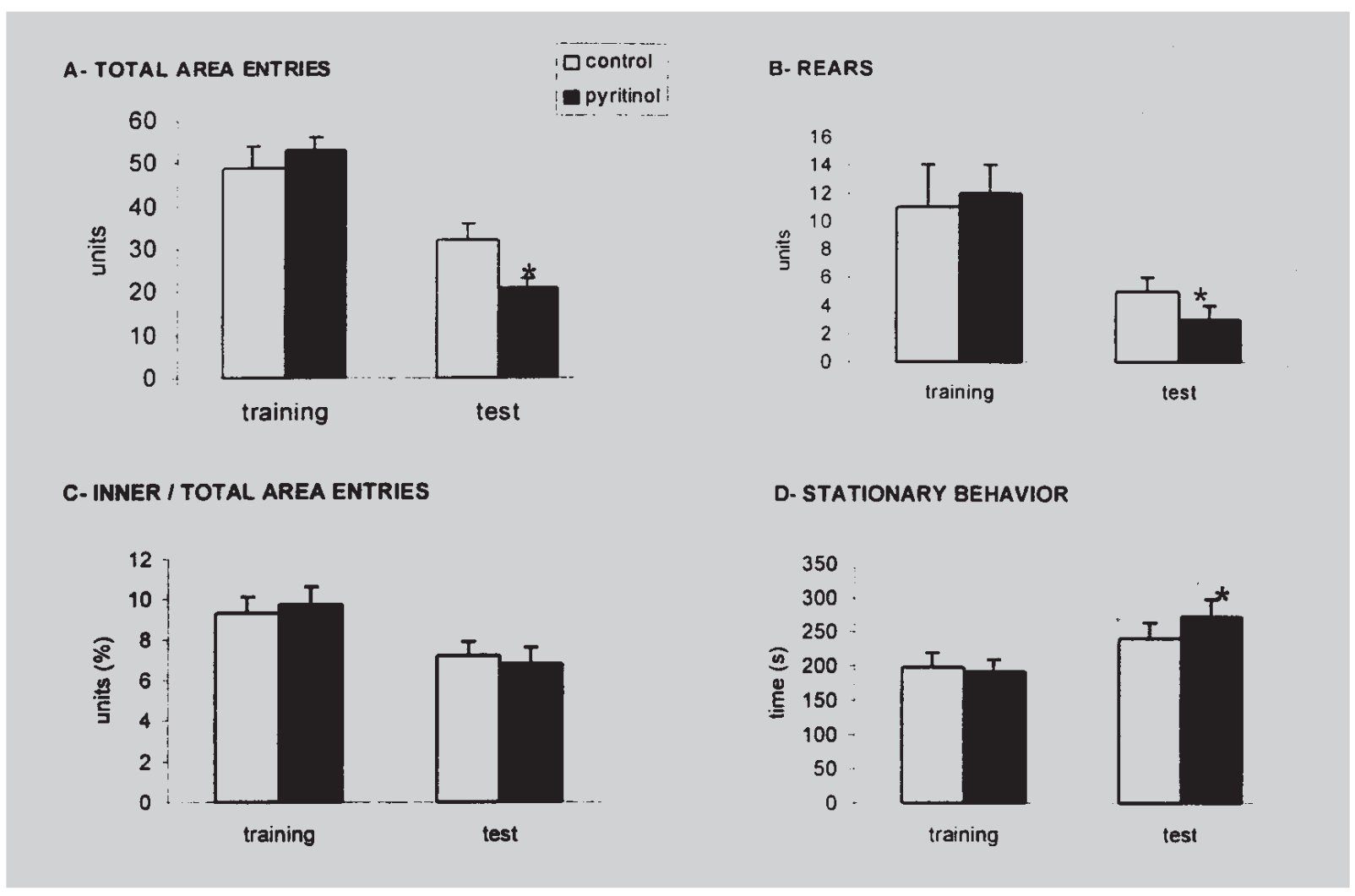

FIGURE 1 - Effects of pyritinol in the behavior of aged rats observed in an open field. Rats $(n=10)$ were treated PRT $(200 \mathrm{mg} / \mathrm{kg} /$ day, p.o. for 14 days $)$ or in absence of drug $(n=8)$ during open field task. Histograms represent mean \pm SD for indicated animals number $(\mathrm{N})$ observed in the open field. $* \mathrm{P}<0.05$ compared to session of control group (vehicletreated rats) post hoc comparisons after Kruskal-Wallis. 
The decrease of exploratory activity following repeated exposure to the same environment is taken as a measure of retention. The results of this present experiment showed that repeated exposure to the open field caused a reduction of the number of total entries and rears, indicating habituation. These effects were increased by PRT treatment, suggesting that this drug improved retention. This effect of PRT is probably mediated by its actions on central muscarinic cholinergic system of aged rats, as described by others (Koph, Baratti, 1996; File, 1976; Carlton, 1968).

The performance in open field and other behavioral paradigms have been proposed as a behavioral index of "anxiety" (Pellow et al., 1985; Hall, 1934). Anxiety is generally inferred from measures assessing the animal's propensity to approach/avoid to enter the inner areas of the open field (Berlyne, 1960). The ratio of inner to total area entries in animals treated with PRT was not different from that of the control animals, indicating that behavioral habituation observed in animals treated with PRT cannot be attributed to the degree of anxiety.

In addition to anxiety-induced avoidance, it has long been recognized that the exploratory behavior directed toward a novel stimulus is modulated by the "curiosity"induced approach. This process is determined by organism's sensitivity to the positive incentive-motivational properties of the stimulus (Rowe et al., 1998; File, 1990; Montgomery, 1953). Consequently, the PRT rats were more sensitive to the positive incentive properties of the novel stimuli when compared to the controls. These arguments raised above suggest that the behavioral habituation induced by PRT cannot be attributed to an increase in anxiety. Finally, it could be argued that PRT animals were more able to recall previous stimulus exposures.

\section{CONCLUSION}

Taken as a whole, present study shows the effects of PRT in habituation of exploratory activity on the open field in aged rats and suggest that muscarinic cholinergic systems could participate on the behavioral effect of the drug. These findings, however, should be extended to other cognitive performances to provide additional support to that view of PRT effect in the memory.

\section{ACKNOWLEDGMENTS}

The authors are grateful to the Prof. M. C. W. Avellar and Prof. C. S. Planeta for helpful discussion and M. A. G. S. Fernandes for technical assistance.

\section{RESUMO}

\section{Habituação da atividade exploratória em ratos idosos: efeitos do piritinol}

A acetilcolina é um neurotransmissor que desempenha considerável papel crítico nos processos subjacentes ao comportamento, aprendizagem e memória. Piritinol (piritioxina, Encefabol ${ }^{\circledast}$, PRT) é um fármaco nootrópico que aumenta a transmissão colinérgica no sistema nervoso central. Habituação comportamental seguida de múltipla exposição no campo aberto é um paradigma experimental freqüentemente usado na avaliação das ações cognitivas de fármacos. Neste paradigma, a diminuição da atividade exploratória em função da exposição repetida ao mesmo ambiente é considerada como índice de memória. No presente estudo, os efeitos do piritinol (PRT) na forma de pó adicionado a dieta (200 mg/kg/dia, p.o., durante 14 dias) sobre a habituação em ratos idosos foram avaliados no campo aberto. Um total de 18 ratos idosos foram randomizados e divididos em dois grupos: controle (tratado com veículo, $n=8$ ) e experimental (tratado com PRT, n=10). Na avaliação da tarefa exploratória, o tratamento com PRT diminuiu significantemente os números totais de área cruzada e do levantar quando comparados com o grupo controle, indicando habituação. O tratamento com PRT aumentou a retenção no número total de cruzamentos e levantar quando comparado com o grupo controle. A análise dos dados em conjunto, sugere que o sistema muscarínico colinérgico pode estar envolvido com os efeitos da PRT sobre a habituação da atividade exploratória em ratos idosos.

UNITERMOS: Habituação. Campo aberto. Piritinol. Memória. Sistema colinérgico.

\section{REFERENCES}

BARTUS, R. T.; DEAN, R. L.; BEER, B.; LIPPA, A. S. The cholinergic hypothesis of geriatric memory dysfunction. Science, Washington, v. 217, p. 408-417, 1982.

BARTUS, R.T.; DEAN, R. L.; FLICKER, C. Cholinergic psychopharmacology: An integration of human and animal research on memory. In: MELTZER, H. Y., (Ed.). Psychopharmacology: the third generation of progress. New York: Raven Press, 1987. p. 219-232. 
BERLYNE, D. E. Conflict, Arousal and Curiosity. New York: McGraw-Hill, 1960.257p.

CARLTON, P. L. Brain-Acetylcholine and habituation. Prog. Brain Res., Amsterdam, v. 28, p. 48-60, 1968.

COOPER, A. J.; MAGNUS, R. Memory for discourse in old age. Cognit. Psychol., Duluth, v. 11, p. 412-429, 1981.

DELUCIA, R.; AIZENSTEIN, M. L.; PLANETA, C. S. Effect of fencamfamine on avoidance performances of rats. Brazilian J. Med. Biol. Res., Ribeirão Preto, v. 24, p. 307-309, 1991.

DOLCE, G. Neurophysiologische Undersuchunngen zur Wirkung von Pyrithioxin auf das Zentrale Nervensystem der Katze, Pharmakopsychiatric. Neuropsychopharmacology, New York, v. 3, p. 355-361, 1970.

FIBIGER, H. C. Cholinergic mechanism in learning, memory and dementia: review of recent evidence. Trends Neurosci., Amesterdam, v. 14, p. 220-223, 1991.

FILE, S. A. Are central cholinergics paths involved in habituation of exploration and distraction? Pharmacol. Biochem. Behav., Phoenix, v. 4, p. 695-702, 1976.

FILE, S. E. Interactions of anxiolytic and antidepressant drugs with hormones of the hypothalamic-pituitary-adrenal axis. Pharmacol. Ther., Oxford, v. 46, p. 357-375, 1990.

GOLD, P. E. Acetylcholine modulation of neural systems involved in learning and memory. Neurobiol. Learn. Mem., San Diego, v. 80, p. 194-210, 2003.

HALL, C. S. Emotional behavior in the rat. 1. Defecation and urination as measures of individual differences in emotionally. J. Comp. Physiol. Psychol., Washington, v. 18, p. 385-403, 1934.

HOYER, S.; OESTERRELCH, K.; STOLL, K. D. Effects of pyritinol-HCl on blood flow and oxidative metabolism of the brain in patients with dementia. Arzneimittelforschung, Aulendorf, v. 27, p. 671-674, 1977.

IBACH, B.; HAEN, E. Acetylcholinesterase inhibition in Alzheimer's disease. Curr. Pharm. Des., v. 10, p. 231$251,2004$.
JUDD, L. L.; SQUIRE, L. R.; BUTTERS, N.; SALMON, D. P.; PALLER, K. A. Effect of psychotropic drugs on cognition and memory in normal humans and animals. In: MELTZER, H. Y.(Ed.). Psychopharmacology: the third generation of progress. New York: Raven Press, 1987, p. 1467-1476.

KNEZEVIC, S.; MUBRIN, Z.; RISBERG, J.; VUCINIC, G.; GUBAREV, N.; WANNENMACHER, W. Pyritinol treatment of SDAT patients: evaluation by psychiatric and neurological examination, psychometric testing and RCBF measurements. Int. Clin. Psychopharmacol., London, v. 4, p. $25-38,1989$.

KOPH, S. R.; BARATTI, C. M. Effects of post-training administration of glucose on retention of a habituation response in mice: participation of central cholinergic mechanism. Neurobiol. Learn. Mem., San Diego, v. 65, p. 253-260, 1996.

LAMPREA, M. R.; CARDENAS, F. P.; SILVEIRA, R.; WALSH, T. J.; MORATO, S. Effects of septal cholinergic lesion on rat exploratory behavior in an openfield. Braz. J. Med. Biol. Res., Ribeirão Preto, v. 36, p. 223-228, 2003.

MARTIN, J. L. On the mechanism of action of encephabol. J. Int. Med. Res., Northampton, v. 11, p. 55-65. 1983.

MARTIN, K. J.; VYAS, S. Increase in acetylcholine concentration in the brain of old rats following treatment with pyrithioxine (Encephabol). Br. J. Pharmacol., London, v. 90, p. 561-569, 1987.

MARTIN, K. J.; WIDDOWSON, L. Acetylcholine synthesis and membrane phospholipids. In: MAUER, K.; RIEDERER, P.; BECKMANN, H., (Eds.). Alzheimer's disease. Epidemiology, Neuropathology, Neurochemistry, and Clinics. Wien: Springer-Verlag, 1990. p. 225-228.

MOLIENGO, L.; ORSETTI, M.; PASTORELLO, B.; SCORDO, I.; GHI, P. Habituation of exploratory activity in rats: action of N6phenylisopropyladenosine, caffeine and their combination. Prog. Neuro-Psychopharmacol. Biol. Psychiatr., Oxford, v. 19, p. 1189-1200, 1995.

MONTGOMERY,K. C. Exploratory behavior as function of similarity of stimulus situations. J. Comp. Physiol. Psychol., Washington, v. 46, p. 129-33, 1953. 
PELLOW, S.; CHOPIN, P.; FILE, S. E.; BRIELY, M. Validation of open:closed arm entries in an elevated plus maze as measure of anxiety. J. Neurosci. Methods, Amsterdam, v. 14, p. 149-167, 1985.

ROWE, W. B.; SPREEKMEESTER, E.; MEANEY, M. J.; QUIRION, R.; ROCHFORD, J. Reactivity to novelty in cognitively-impaired and cognitively-unpaired aged rats and young rats. Neuroscience, Oxford, v. 83, p. 669-680, 1998.

SCHILDEIN, S.; HUSTON, J. P.; SCHWARTING, R. K. Open field habituation learning is improved by nicotine and attenuated by mecamylamine administered postrial into nucleus accumbens. Neurobiol. Learn. Mem., San Diego, v. 77, p. 277-290, 2002.

THIEL, C. M.; HUSTON, J. P.; SCHWARTING, R. K. Hippocampal acetylcholine and habituation learning. Neuroscience, Oxford, v. 85, p. 1253-1262, 1998.
WILLIANS, I. M.; HAMILTON, L. W.; CARLTON, P. L. Pharmacological and anatomical dissociation of two types of habituation. J. Comp. Physiol. Psychol., Washington, v. 87, p. $724-732,1974$.

WHITEHOUSE, P. J. Neuronal less and neurotransmitter receptor alteration in Alzheimer's disease. In: FISHER, J. A.; HANIN, I.; LACHMAN. C. (Eds.). Alzheimer's and Parkinson's diseases: strategies for research and, development. New York: Plenum Press, 1986, p. 85-94.

ZYHOV, V. P.; BEGASHEVA, O. I. Cognitive disturbances in patients with tics and Tourette's syndrome and their correction with encephabol. Zh. Nevrol. Psikhiatr. Im. S. S. Korsakova, Moscow, v. 10-14, 2003.

Recebido para publicação em 29 de julho de 2004. Aceito para publicação em 17 de novembro de 2004. 